\title{
Domestic Religion and Connected Spaces: Isabella della Rovere, Princess of Bisignano (1552-1619)
}

\author{
Elisa Novi Chavarria
}

The concept of 'domestic religion' is certainly rich in interpretative potential; for example, it is useful in overcoming the restrictions inherent in the term 'civic religion', focussed as this is on the space and time of rituals and of religious festivity and collective devotional fervour. ${ }^{1}$ It also avoids dichotomies such as high/low, noble/popular, or theory/practice, as well as many other fetters and impediments which have hindered scholars in approaching the idea of 'popular religion'. We can add this to Giuseppe Galasso's lucid interpretation of popular religion, which sidesteps sociology and class to define it as something simple, elemental and traditional (as historically determined). ${ }^{2}$ Similarly, the usefulness of the concept of 'domestic religion' also lies in its ability to overcome the dichotomies intrinsic in the categories of 'centre/ periphery' and 'confessionalisation/regulation' which have had a notable impact on the history of ecclesiastical structures and regulation, relating as they do to the modernisation of bureaucracy and procedure, leaving aside the questions of religious intimacy, pluralism, and the dissemination of rituals. ${ }^{3}$ Above all, the concept of domestic religion fundamentally challenges the idea of a monolithic Catholic culture. Here, I emphasise the role of local groups in the promotion of religious renewal, and in particular the part played by women and their network of relationships.

1 On the use of this concept in early modern Naples, see Marino J.A., Becoming Neapolitan: Citizen Culture in Baroque Naples (Baltimore: 2011); Guarino G., "Public Rituals and Festivals in Naples, 1503-1799", in Astarita T. (ed.), A Companion to Early Modern Naples (Leiden Boston: 2013) 257-279.

2 Galasso G., "La storia socio-religiosa e i suoi problemi", in L'altra Europa. Per un'antropologia storica del Mezzogiorno d'Italia (Naples: 2009) 385-401.

3 Novi Chavarria E., "Passato e presente della storiografia socio-religiosa", L'Acropoli 1 (2003) 5468. See also Lotz-Heumann U., 'Confessionalization', in Bamji A. - Janssen G.H. - Laven M. (eds.), The Ashgate Research Companion to the Counter-Reformation (Burlington: 2013) 33-54.

(C) ELISA NOVI CHAVARRIA, 2019 | DOI:10.1163/9789004375871_008

This is an open access chapter distributed under the terms of the prevailing CC-BY-NC-ND License at the time of publication. 
In the following pages I will try to explain, via examination of a specific casestudy, how the concept of 'domestic religion' can be interpreted. In other words, I will try to shed light on how analysis of a network, combined with a social and cultural microhistory, can reveal many of the traits of fluidity and mobility, plurality and transversality that I believe to be part of the 'Confessionalisation' process and the category of 'domestic religion. ${ }^{4}$ It is thanks to this approach that we can better situate religious phenomena within a constantly shifting panorama which was characterised in Naples by intense diversity, and by devotional and cultural pluralism.

As we refine and develop the concept of domestic religion, we need to ensure that it does not solidify into rigid use. The domestic should be considered an open, connected and malleable space. To do this, a methodology must be crafted which interweaves many different sorts of sources, bearing in mind the plethora of possible options. This should combine the practice of research with an awareness of theory - archival work with critical thought. This might help us to navigate to a middle ground, so to speak, between the history of institutions and that of mentalities, between religious history and cultural history, between the sphere of norms and the sphere of behaviours, treading the boundary between ecclesiastical structures, civil power and society, between institutional strictures and individual choices, between capital resources and symbolic systems. ${ }^{5}$ I will come back to this and other similar issues in my conclusion. I will now turn to the analysis of my case-study.

At the heart of our story are two individuals and a devotional image: the historical figures are Princess Isabella della Rovere of the Dukes of Urbino, wife of the Prince of Bisignano Nicolò Bernardino Sanseverino, one of the greatest barons of the Kingdom of Naples, and the blessed Geremia da Valacchia, one of the many 'living saints' who populated the city of Naples at the peak of the Counter-Reformation. Connecting these protagonists was a painting - a

4 Trivellato F., "Is there a Future for Italian Microhistory in the Age of Global History?", Californian Italian Studies 2.1 (2011), permalink: http://escholarship.org/uc/item/o294nghq.

5 Novi Chavarria E., "Controllo delle coscienze e organizzazione ecclesiastica nel contesto sociale", in Chacon F. - Visceglia M.A. - Murgia G. - Tore G. (eds.), Spagna e Italia in Età moderna: storiografie a confronto (Rome: 2009) 305-325: 313 . 
depiction of the Virgin and Child - which came to serve as a means of the circulation and sharing of a transnational cult.

Isabella is well-known to historians - and to historians of art and of the Counter-Reformation in particular - as the generous benefactress of Jesuits in Naples and in Rome, and as a sensitive patron and collector of Renaissance art works. She was born on 1 August $155^{2}$ to Guidobaldo II della Rovere, Duke of Urbino and his second wife, Vittoria Farnese, who was the sister of Ottavio, Duke of Parma and of cardinal Alessandro Farnese, and the granddaughter of Pope Paul III. Isabella was brought up in the refined Renaissance courts of Pesaro and Urbino, where as a child she met scientists, mathematicians, prelates, artists and scholars, including Federico Zuccari, Federico Barocci, Bernardo Tasso and a young Torquato Tasso. Her teachers were probably the same as those who educated her brother Francesco Maria in literature and mathematics, which is to say Vincenzo Bartoli from Urbino and Ludovico Corrado from Mantua. In addition, her mother instructed her in the more complex world of informal diplomacy and political negotiation, in the patronage of the arts, and in tending to the emotional well-being of relationships within the family. ${ }^{6}$ Isabella placed special importance on relationships with other gentlewomen within the household and the court (the leading lights during Isabella's childhood were Ginevra Malatesta, Pantasilea Baglioni, Cornelia Varano, Ippolita Pico and her cousin Clelia Farnese, the natural daughter of cardinal Alessandro). Bernardo Tasso mentioned her, along with her mother and her sister Lavinia, in his heroic poem Amadigi, first published in Venice in $1560 .{ }^{7}$ Five years later, in 1565 , Isabella married the prince of Bisignano, heir to one of the biggest, and to one of the most heavily indebted, feudal states within the kingdom of Naples. ${ }^{8}$

6 Becker S., Dynastische Politik und Legitimationsstrategien der della Rovere Potenziale und Grenzen der Herzöge von Urbino (1508-1631) (Rome: 2015).

7 A hagiographic biography of Isabella can be found in Napoli, Biblioteca Nazionale (hereafter BNN), ms. XI A 52, Della vita e morte dell'ill.ma et Ecc.ma S.ra Donna Isabella Feltria della Rovere, Principessa di Bisignano. On the text and on Isabella see Conelli M.A., "The Ecclesiastical Patronage of Isabella Feltria della Rovere: Bricks, Bones and Brocades", in Verstegen I.F. (ed.), Patronage and Dynasty: The Rise of the della Rovere in Renaissance Italy (Kirksville, MI: 2007) 123-140. On the text and on Isabella see Miretti M., "Vittoria Farnese: vita pubblica e privata" in Giallongo A. (ed.), Donne di palazzo nelle corti europee. Tracce e forme di potere nell'età moderna (Milan: 2005) 149-157; Miretti M., "Mediazioni, carteggi, clientele di Vittoria Farnese, duchessa di Urbino", in Arcangeli L. - Peyronel S. (eds.), Donne di potere nel Rinascimento (Rome: 2008) 765-784.

8 Becker, Dynastische Politik und Legitimationsstrategien der della Rovere, 183-187. The weddings were celebrated at the Della Rovere court in Pesaro. See Piperno F., L'immagine del Duca. Musica e spettacolo alla corte di Guidubaldo II duca d'Urbino (Florence: 2001) 93-96. 
As biographers would subsequently relate, hers was not a happy marriage. After a brief period spent in a house belonging to the Della Rovere family in Pesaro, the young couple moved to properties owned by the Sanseverino in Calabria. There, ensconced in provincial isolation in the castles of Cassano and Morano, during the long hunting seasons in which her husband took part with gusto, Isabella began to experience the first repercussions of a decidedly mismatched marriage. Despite having around her a small court of ladies-in-waiting which she had brought with her from Urbino, Isabella was hurt by the backbiting and intrigue of the Prince's entourage. She was homesick for the sophisticated setting of the court she had grown up in. Above all, though, she was wounded by the indifference and frequent absences of her husband. ${ }^{9}$ She complained about it repeatedly in the letters she wrote to her mother, and in the prolific correspondence she maintained up to her death, both with other members of her large extended family, and also with Giulio Giordano, a gentleman from Pesaro who had acted as secretary for her husband, the Prince of Bisignano for some time. ${ }^{10}$ To cope with her unhappy marriage and escape the oppressive atmosphere of her Calabrian home, she took to travelling: a brief stay in Urbino, and pilgrimages with her mother and her sisters to Assisi and the sanctuary of Loreto in $1567 \cdot{ }^{11}$

In 1571, to coincide with the arrival of Don John of Austria who was organising the expedition against the Turks, the couple moved to the beautiful Chiaia palace in Naples, where they led a luxurious court life, going to parties, balls and plays. At the same time, marital relations were becoming increasingly strained, such that Isabella spent another two periods apart from her husband, going to stay with the Cesarini family in Rome, where she enjoyed the care of her cousin Clelia, who welcomed her into her own home, and encouraged her to join in with the lively social life she led. ${ }^{12}$

Being troubled by a painful lesion on her nose, Isabella temporarily made up with her husband only at the beginning of the 1580 s. It was then that she managed to fulfil her wish to be a mother and to provide an heir to the dynasty with the birth, in 1581, of her son Francesco Teodoro. In those years, following

9 Della vita e morte dell'Ill.ma et Ecc.ma S.ra Donna Isabella Feltria della Rovere, fols. $5{ }^{\mathrm{r}-7 \mathrm{v} \text {. }}$

10 Some of this correspondence is in ASP, Carteggio Farnesiano Estero, Urbino, b. 591.

11 See Vernarecci A., Lavinia Feltria Della Rovere, marchesa del Vasto da documenti inediti (Rome: 1924) 24 and for additional thoughts on Isabella's marriage and familial relations.

12 Fragnito G., Storia di Clelia Farnese. Amori, potere, violenza nella Roma della Controriforma (Bologna: 2013) 131, 279. 
in her own mother's footsteps, Isabella also began to put in order the precarious Sanseverino finances, overseeing the reorganisation of the accounts both by streamlining spending and calling in old loans, as well as by doing away with certain privileges which the local nobility had usurped to give to vassals in their Calabrian estates. ${ }^{13}$ In 1577 she got her husband to put the estate of Policoro in Basilicata in her name. Three years after this he transferred to her a considerable proportion of the (fiscal) yield on the customs duty on silk to the tune of 4,000 ducats, managing to extract this from the sequestration which had been placed upon the entire Bisignano patrimony. ${ }^{14}$ Isabella made use of her own talents and of her social network to secure the support of the viceroy of Naples Don Juan de Zúniga. He, spurred on by the urgent requests which came from the court of the dukes of Urbino, personally undertook to keep track of what happened to Isabella - though he managed neither to alleviate the numerous debts which her husband the prince had run up, nor to stop the sequestration, and much less to lift Isabella's spirits from a marriage which seemed unhappier every day. On 23 December 1581 Zúñiga informed Francesco Maria Della Rovere that the question of the Prince of Bisignano's assets 'is settled suitably' although 'there is great difficulty ascertaining them with precision', and therefore it would have been best to hope for the lesser evil. He added that he had advised the Princess (who in the meantime had expressed the wish to leave Castle Morano and move back to Naples) that he thought she should not abandon her conjugal home in Calabria. ${ }^{15}$

In Calabria, Isabella who, as we know, was a devoted follower of the Jesuits, was in contact with several members of the newly-formed Society of Jesus from the late 156os, when she had been visited by two Jesuit missionaries, Lucio Croce and Juan Xavier, who were sent into the Valdesian community that existed on her estates. ${ }^{16}$ These were the very same Jesuits who, at the same moment, in communication with the people of the Calabrian countryside and mountains, developed the metaphor of the Indias de por açà. This became a topos in contemporary missionary literature as a way of suggesting that, right in the heart of Catholic Europe, and in the South of Italy in particular, there

13 Galasso G., Economia e società nella Calabria del Cinquecento (Naples: 1992) 3-16.

14 AнN, legajo 3948, Papeles referentes al Principe Bisiniani y a su mujer Isabella de la Rovere.

15 BL, MS Add 28.413, Register of letters of Juan de Zuñiga Ambassador at Rome Spanish, vol. VI, June 1581-Aug. 1582, fols. 242v-243r. Other letters from Juan de Zúñiga to the dukes of Urbino and to the princess of Bisignano are at fols. $82 \mathrm{~V}-85 \mathrm{~V}, 242 \mathrm{~V}-243 \mathrm{r}$.

16 Marranzini A., "I gesuiti Bobadilla, Croce, Xavierre e Rodriguez tra i Valdesi di Calabria", Rivista storica calabrese 4 (1983) 121-129. 


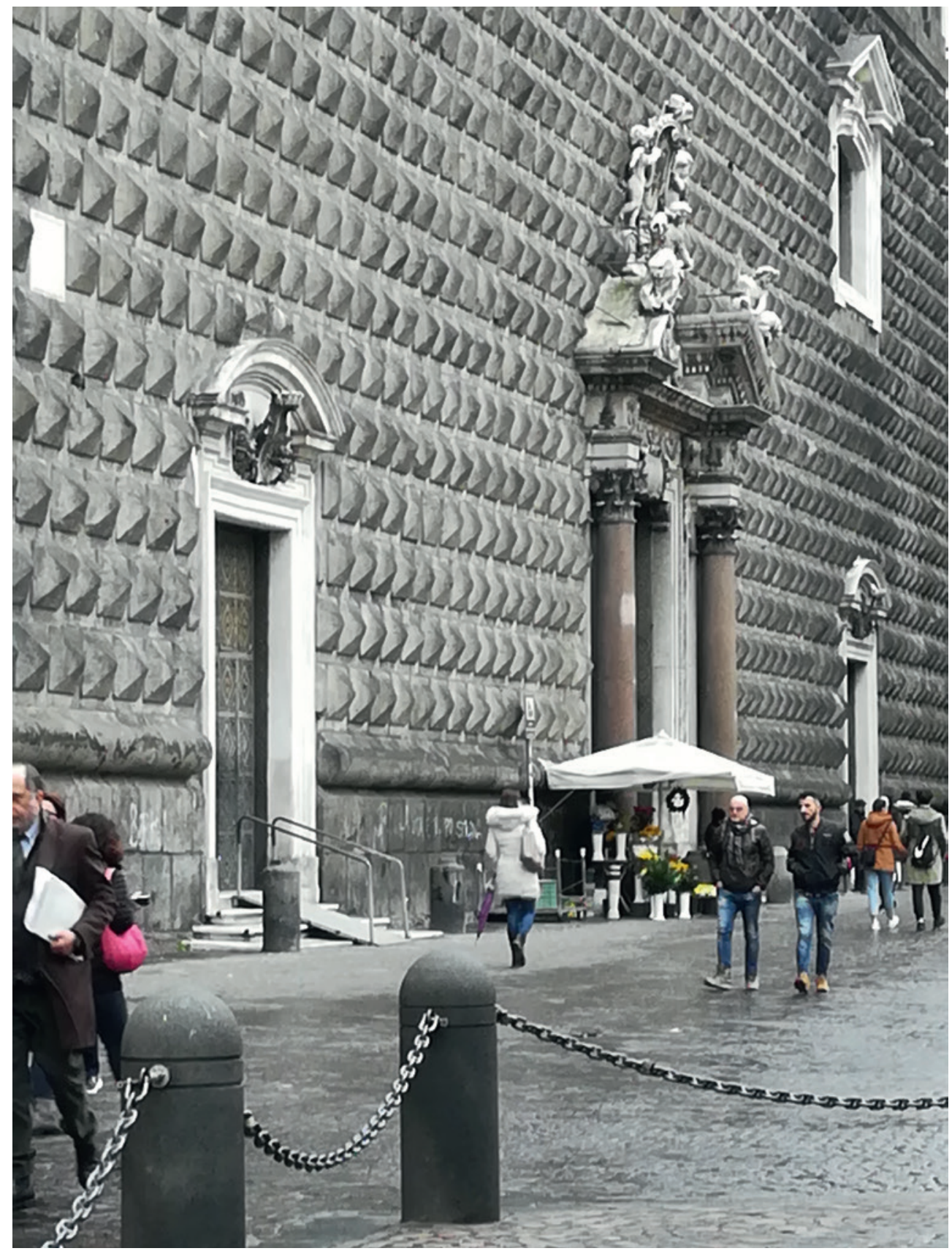

FIGURE 6.1 The Church of Gesù Nuovo, Naples, 16th-18th centuries PHOTOGRAPH BY THE AUTHOR 
were communities characterised by such cultural backwardness and ignorance even of the basics of faith and of Christian doctrine that they could be grouped together with the indigenous populations of distant lands. ${ }^{17}$

Isabella took the message of the two Jesuits to heart. She started to finance them in their catechetical activities and in offering spiritual succour to her servants. When later she moved more or less permanently to Naples and the Chiaia Palace, the princess started frequently to attend the 'Casa Professa' run by the Jesuits in that city, to whom she regularly gave sums of money, precious objects, and a great many relics. Her financial support to the church of Gesù Nuovo was so generous that she was named the founder of the edifice, and her name can be read to this day in a stone of the tympanum over the main door [Figs. 6.1-6.2].

At the same time Isabella subsidised other institutions alongside the Jesuits: the College of the Massalubrense, near Naples; the novitiate of San Vitale in Rome (which at that time also received patronage and financial support of her uncle, the cardinal Alessandro Farnese); the brothers of the Order of San Francesco of Paola in Calabria; and, in Naples, the convents of Santa Maria della Sanità and Santa Maria del Carmine, and the Ospedale degli Incurabili, which she visited regularly, tending to the sick alongside the countess of Miranda, María de Zúñiga y Avellaneda, vicereine of Naples. It cannot be ruled out that she did this in part to keep safe a hefty slice of the family fortune, already lacerated by her husband's debts, from the clutches of creditors. But in Counter-Reformation Naples, in the years between the end of the sixteenth century and the beginning of the seventeenth, and in the pages of her appreciative biographers - who were none other than her own Jesuit confessors and spiritual fathers - the princess became a model of Christian virtue. She was praised for her attentiveness to the sacraments and to devotional practises, her modesty and spotless conduct, the patience with which she was able to face sickness, sacrifice and, eventually, the pain of the untimely death of her son in 1595, at only fourteen years old [Fig. 6.3]..$^{18}$

17 Prosperi A., Tribunali della coscienza. Inquisitori, confessori, missionari (Turin: 1996) 551599; Novi Chavarria E., "Las Indias de por açà nelle relazioni dei gesuiti napoletani", in Il governo delle anime. Azione pastorale, predicazione e missioni nel Mezzogiorno d'Italia. Secoli XVI-XVIII (Naples: 2001) 141-156; Selwynn J., A Paradise Inhabited by Devils: The Jesuits' Civilizing Mission in Early Modern Naples (Aldershot: 2004). 


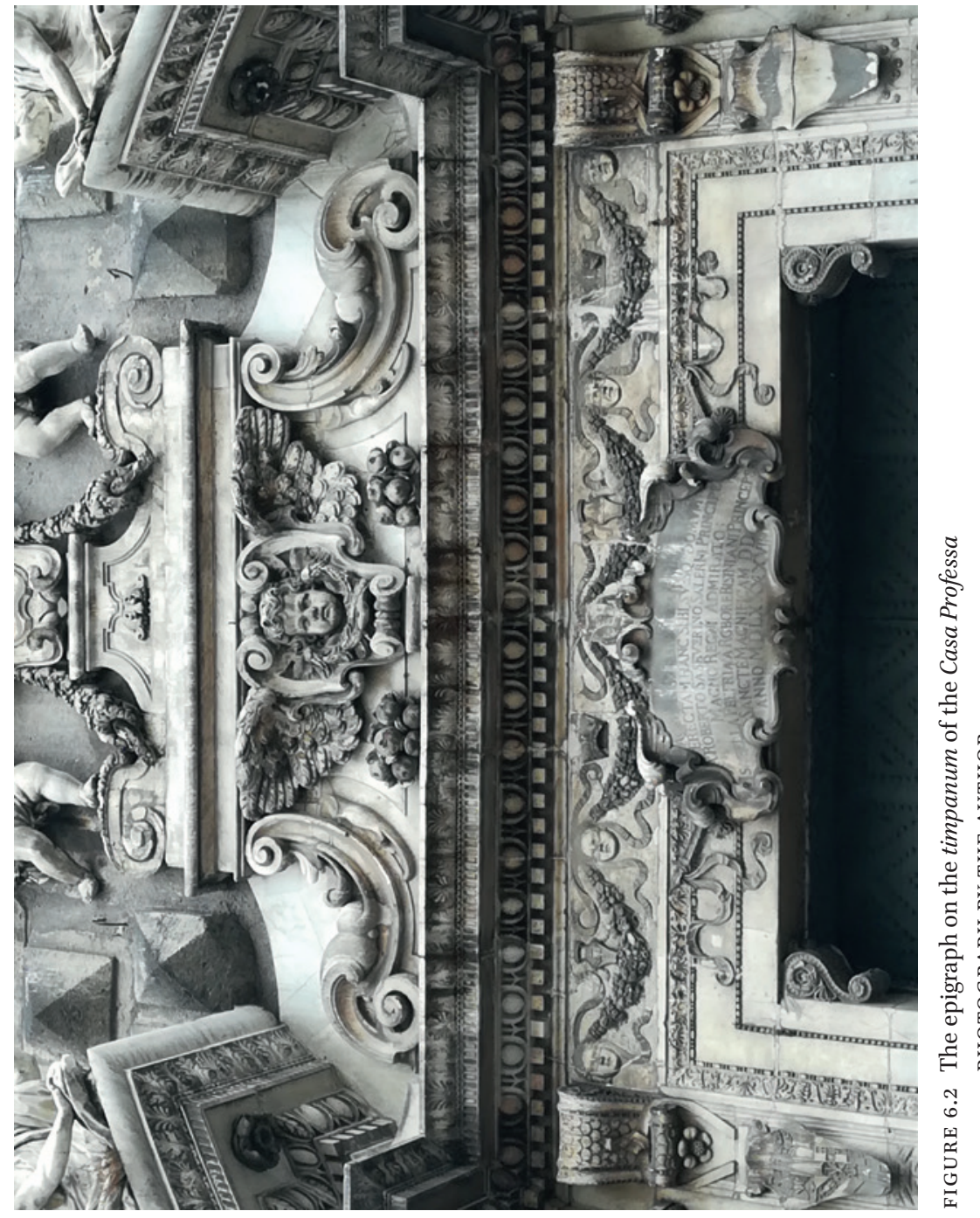


This study argues, however, that the princess of Bisignano was not merely a typical example of a 'charitable and pious noblewoman', as many have described her [Fig. 6.4]. ${ }^{19}$ She participated actively in courtly cultural life in Urbino and in Naples, where she garnered sincere admiration and recognition from the many scholars who dedicated their works to her, including the aforementioned Bernardo Tasso, the poet Laura Terracina, the Jesuit Luca Pinelli, the Neapolitan historian Angelo di Costanzo and the poet Pietro Campollonio [Fig. 6.5]. ${ }^{20}$ She upheld the artistic and cultural connections that her own family, the Della Rovere, had with the Habsburg Court in Madrid, through which she commissioned several works from Federico Barocci, as well as other diplomatic gifts, amongst which were scientific instruments, watches and small luxury items, in addition to an extraordinary number of devotional objects, such as reliquaries, sacred images and agnus dei. ${ }^{21}$ Her collection of scientific items went hand in hand with her collection of religious material. It was her recommendation that brought the Calabrian-born artist Felice Antonio Lettieri to the court of her brother Francesco Maria II; from 1603, Lettieri took on the role of supervisor of the artisanal workforce employed in the Della Rovere household in Pesaro. ${ }^{22}$ She had a political sensitivity and a rare gift for mediation, as emerges from her regular correspondence with the court in Urbino, which entrusted her with a key diplomatic role to the court of the viceroy and vicereine of Naples. She was at the centre of a huge network which took in communications between Naples, Pesaro, and Rome, but also, as we shall

19 Examples include Conelli M.A., "A typical patron of extraordinary means: Isabella Feltria Della Rovere and the Society of Jesus", Renaissance Studies 18 (2004) 412-436; Conelli M.A., "The Ecclesiastical Patronage of Isabella Feltria della Rovere".

20 Orlandi A., "Donne nelle dediche", in Santoro M. (ed.), La Donna nel Rinascimento meridionale, Atti del Convegno Internazionale (Roma, 11-13 novembre 2009), Istituto Nazionale sul Rinascimento Meridionale, (Pisa-Rome: 2010) 383-392: 388.

21 See Pérez de Tuleda Gabaldón A., "Las relaciones artísticas de la familia della Rovere con la corte española durante el reinado de Felipe iI en la correspondencia del Archivo de Estado de Florencia", in Martínez Millán J. - Rivero Rodríguez M. (eds.), Centros de poder italianos en la monarquía hispánica (siglos XV-XVIII) (Madrid: 2010) vol. III: 1543-1714; Denunzio A.E., "Isabella della Rovere e Isabella Gonzaga a Napoli: originali apporti collezionistici per via di matrimonio", in Denunzio A.E. - Di Mauro L. - Muto G. - Schütze S. - Zezza A. (eds.), Dimore signorili a Napoli. Palazzo Zevallos Stigliano e il mecenatismo aristocratico dal XVI al XX secolo, Convegno Internazionale di Studi (Napoli, 20-22 ottobre 2011) (Naples: 2013) 366-383.

22 See Morselli R., "In the Service of Francesco Maria II della Rovere in Pesaro and Urbino (1549-1631)", in Fumagalli E. - Morselli R. (eds.), The Court Artist in Seventeenth-Century Italy (Rome: 2014) 49-93. 


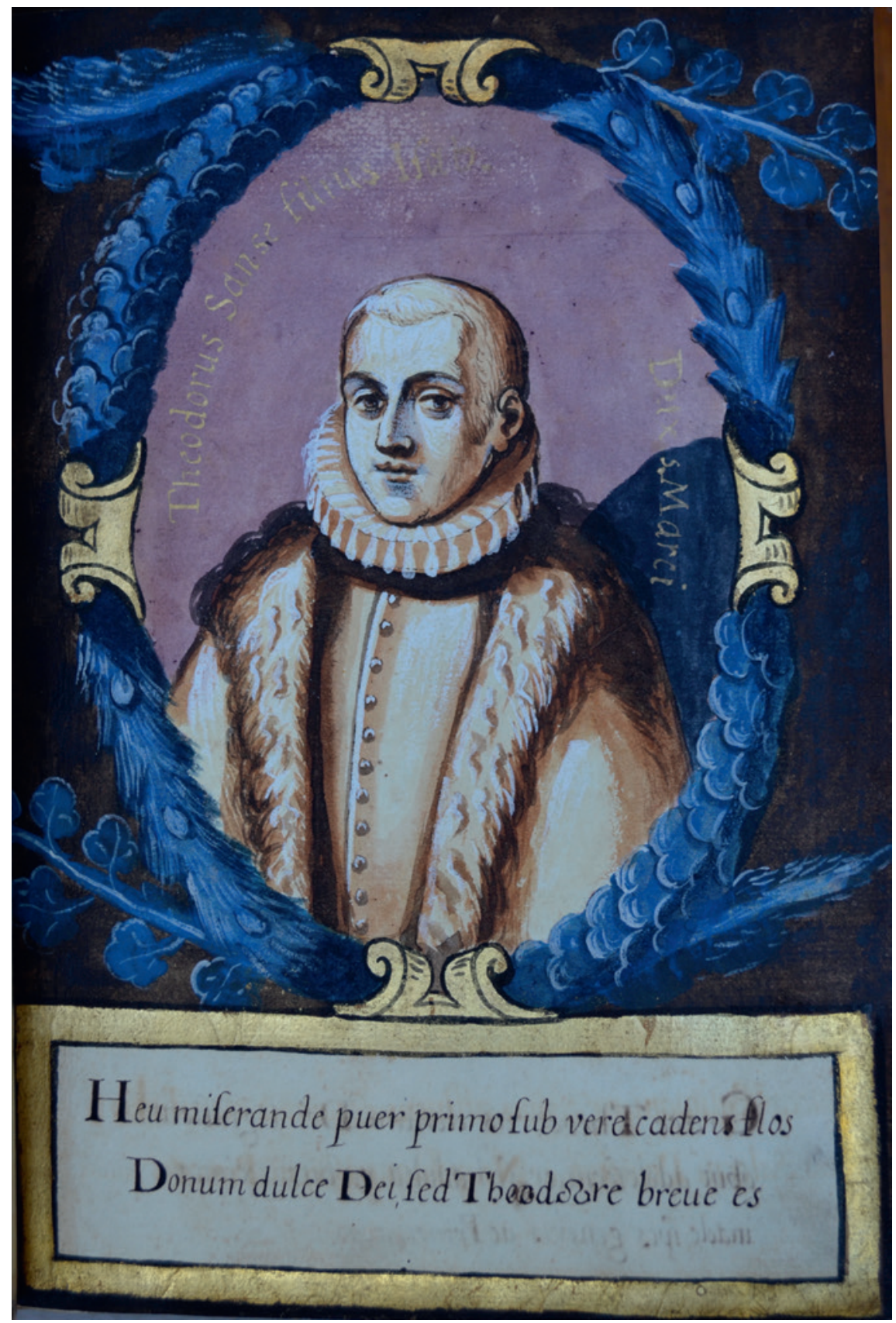

Figure 6.3 Portrait of Francesco Teodoro Sanseverino, BNN, ms. I B 36 G.B. Masculo (S.J.), Isabellae Feltriae Roboreaque principis Bisiniani [...] (Naples 1619)

(C) BIBLIOTECA NAZIONALE DI NAPOLI 


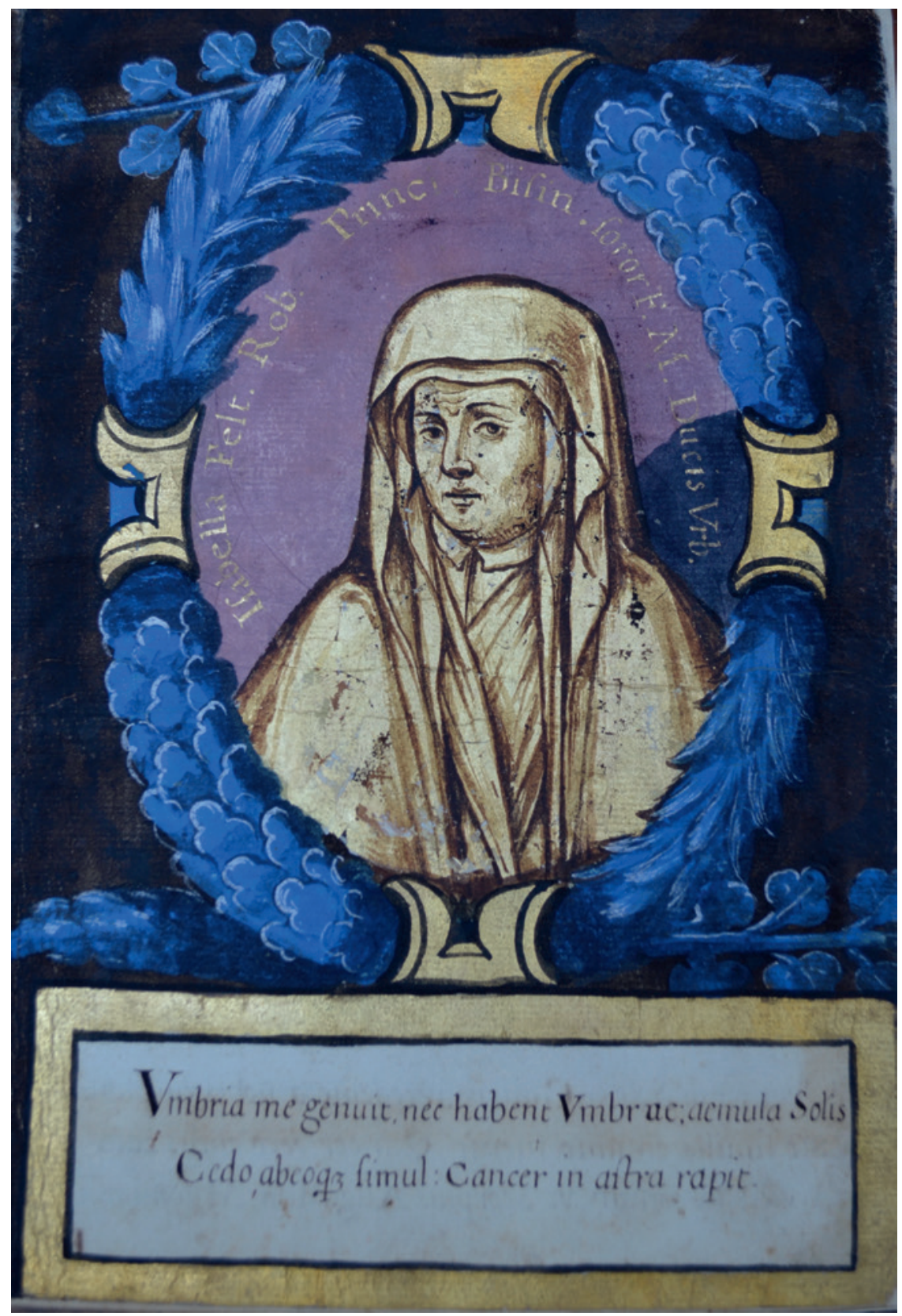

FIGURE 6.4 Portrait of Isabella della Rovere, BNN, ms. I B 36, G.B. Masculo (S.J.), Isabellae Feltriae Roboreaque principis Bisiniani [...] (Naples 1619)

(c) BIBLIOTECA NAZIONALE DI NAPOLI 


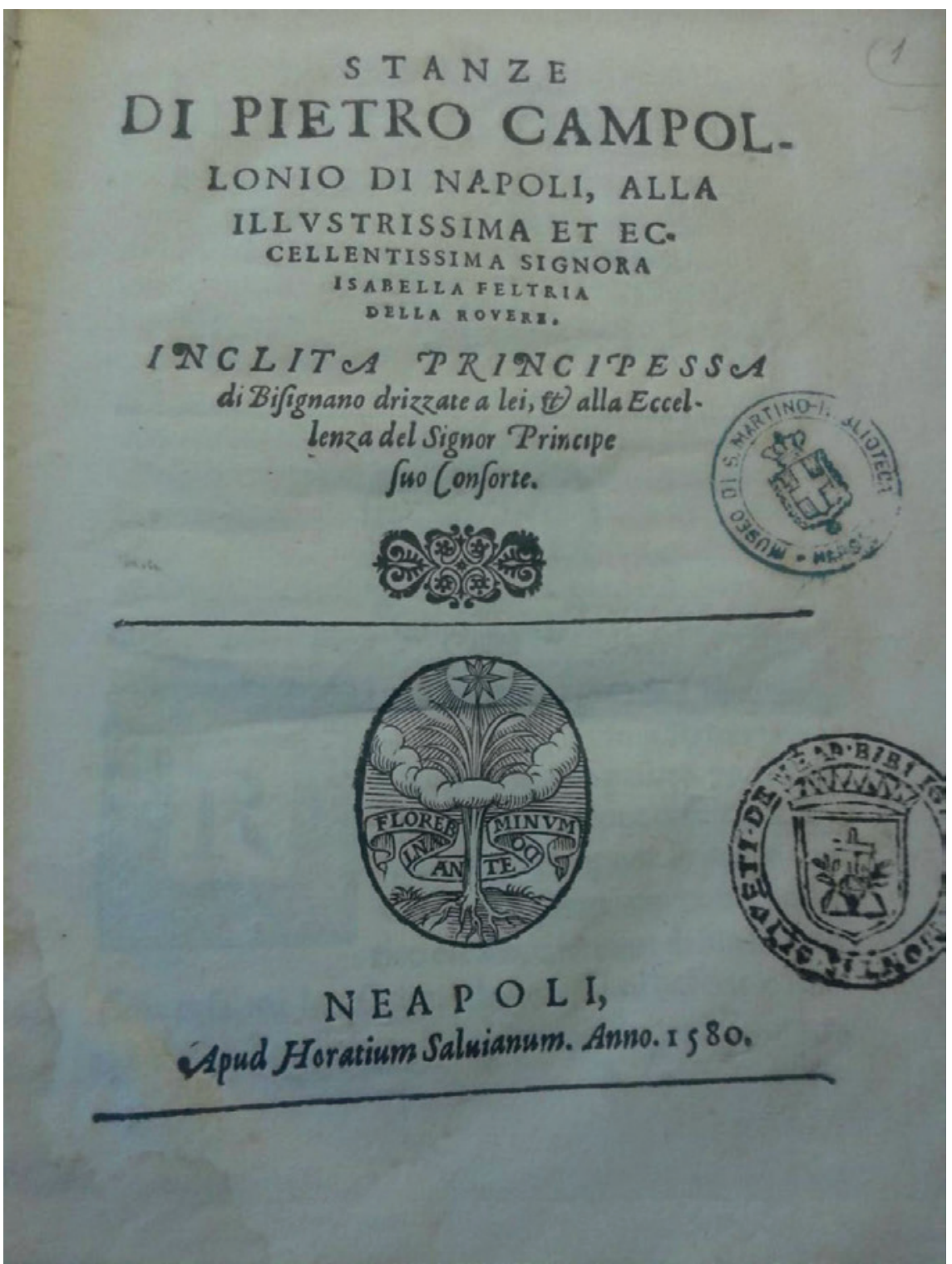

Figure 6.5 P. Campollonio, Stanze di Pietro Campollonio di Napoli, alla illustrissima et eccellentissima signora Isabella Feltria della Rovere [...] (Naples 1580) 
see, budding religious practices and circles of believers. ${ }^{23}$ Thus she stands out among those many 'powerful noblewomen' who populated the courts of Renaissance Italy. ${ }^{24}$ She was, in short, the rightful heir to her mother Vittoria Farnese and to her other forebears on her father's side, who in the mid-sixteenth century catapulted the small duchy from Padana into the orbit of imperial Spanish power. ${ }^{25}$

Upon her death, on 6 July 1619, at the funeral laid on by her brother the duke in Urbino, the elegy was spoken in Latin by Giulio Cesare Capaccio, canon and member of the Academy degli Oziosi (or 'Idlers' Academy'), a versatile writer and acute observer of contemporary Naples. ${ }^{26}$ In Naples, where Isabella had spent most of her life, the Jesuits set aside a theatrical and encomiastic tomb for her, with lavish decoration in gold and lapis lazuli, entrusting the decorative and symbolic display to the ingenious Giovanni Battista Mascolo, also a player in the cultural life of the Neapolitan scientific academies. Mascolo's design celebrated Isabella's significance as a public figure, and her artistic and religious patronage, with solemn funeral honours. ${ }^{27}$

23 Pérez de Tuleda Gabaldón A., "Las relaciones artísticas".

24 See Novi Chavarria E., "Dame di corte, circolazione dei saperi e degli oggetti nel Rinascimento meridionale", in Santoro M. (ed.), La donna nel Rinascimento meridionale $215^{-225}$.

25 Spagnoletti A., Le dinastie italiane nella prima età moderna (Bologna: 2003) 201. For the political relations of the duchy of Urbino with the Spanish court see Signorotto G., "Urbino nell'età di Filippo II", in Martínez Millán J.(ed.), Felipe II (1527-1598), Europa y la monarquía católica (Madrid: 1998) vol. II, 833-879. On the role of informal diplomacy and cultural diplomacy in the political relations of Spanish Italy, see Carrió Invernizzi D., "Diplomacia informal y cultura de las apariencias en la Italia española", in Bravo C. Quirós Rosado R., En tierra de confluencias. Italia y la Monarquía de España, Siglos XVIXVIII (Valencia: 2013) 99-109.

26 Vernarecci A., Lavinia Feltria Della Rovere 28. For a history of the Accademia degli Oziosi and its role in contemporary cultural life, see de Miranda G., Una quiete operosa:forme e pratiche dell'Accademia napoletana degli Oziosi 1611-1645 (Naples: 2000); Gianfrancesco L., "From Propaganda to Science: Looking at the World of Academies in Early Seventeenthcentury Naples", Californian Italian Studies 3.1 (2012), permalink: http://www.escholar ship.org/uc/item/1kf886k4. See Arbizzoni G., "Emblemi e imprese nell'apparato funebre per Isabella Della Rovere (Napoli 1619)", in Imagines loquentes. Emblemi Imprese Iconologie (Rimini: 2013) 143-175.

27 BNN, ms. I B 36, Masculo G.B. (S.J.), Isabellae Feltriae Roboreaque principis Bisiniani ducis Urbinatuium sororis Parentalia, a Patribus Societatis Jesu in templo domus professae B.M. soluta, Napoli 1619 . 
The other central character of our case study is a Capuchin monk, Geremia da Valacchia, who was born in 1566 in the region of Tzazo in the lower Moldavia under the name of Jon Kostistk, and died in Naples in 1625. Such was his reputation for saintliness, and so many were the miracles which popular faith attributed to him, that a mere four years after his death the process of canonisation was already underway in the tribunal of the archdiocese of Naples. ${ }^{28}$ The other Brothers told of how he had dreamed of moving to Italy since he was a child. Schooled by his parents in the basic tenets of the Catholic faith in a country where at the time Catholics were in a minority in comparison to the orthodox or Turkish populations, he had grown up with the idea that he would be able to find 'good Christians' in the Papal lands. When, at the age of 22, after many trials and tribulations, he reached Naples, he found the churches so well officiated and 'such frequent sacraments, with such a multitude of worshippers', that he was deeply moved. This was the context in which his vocation evolved, and he decided to take the habit of a Capuchin monk in the monastery of the Santissima Concezione. ${ }^{29}$

He was assigned to the care of the sick, a task to which he dedicated himself with great self sacrifice, making himself their protector. He treated them, he healed their putrid and malodourous wounds: 'However great the stink was', witnesses would later say at the tribunal for his beatification, 'he fed them without ever betraying worry or disgust. ${ }^{30}$ On more than one occasion, the support he provided resulted in an extraordinary recovery. Amongst the miraculously healed were many young people and above all children, and, in a world where childhood carried with it a strong risk of mortality, their recovery evidently had a particularly wide appeal, causing something of a commotion. ${ }^{31}$ Brother Geremia's presence in the crowded city streets was reported because of the compassion he showed to the poor, and the simplicity and familiarity

28 ASDN, Fondo Cause dei Santi, 26, Geremia da Valacchia.

29 These reports are taken from the tribunal for his beatification, and from Emmanuele da Napoli, Vita del Venerabile Servo di Dio frate Geremia da Valacchia de' Minori Cappuccini della Provincia di Napoli (Naples, Vincenzo Pauria: 1761).

30 It was not possible to trace the original painting. This is only known in hagiographic sources. See ASDN, Fondo Cause dei Santi, 26, Geremia da Valacchia, f. n.n.

31 On the frequent recurrence of miraculous healings within the context of Neapolitan religiosity see Sodano G., Il miracolo nel Mezzogiorno d'Italia dell'età moderna tra Santi, Madonne, guaritrici emedici (Naples: 2010). Useful points of comparison are in Sangalli M., Miracoli a Milano. I processi informativi per eventi miracolosi nel milanese in età spagnola (Milan: 1993). 
(clearly founded on Franciscan principles) with which he treated the faithful. ${ }^{32}$ In this way there sprung up around him miracles and the belief in these miracles, requests for celestial protection for people's children, expectations and hopes from ever more numerous believers of all social strata: nobles, titleholders, religious, and ordinary people. Among them was the viceroy of Naples the Duke of Ossuna Pedro Téllez Girón.

At the death of Brother Geremia many of his followers, with the monastery's collusion, stockpiled relics from his corpse: they pulled out hair and toenails, they ripped pieces of cloth from his habit, and they then swapped these with friends and relatives for other relics. Thus started a network of sacred souvenirs and remains, which broadened his fan base even further. Within a few days the sacristy of the Chiesa della Concezione was stuffed with silver ex votos given in gratitude for the intercession of Brother Geremia. ${ }^{33}$

What then, is it that unites our two protagonists? The conduit for the link between the Princess of Bisignano and Brother Geremia was a painting depicting the Virgin and Child, which was at the centre of many sensory experiences, and the object of transregional and transnational forms of worship and devotion. The painting hung in the Princess's palace, in her bedroom, beside other paintings of a religious theme, precious artefacts and other objects closest to her heart, all of which she would leave to the Jesuits' Casa Professa in Naples. 'The room in which she mostly dwelt,' wrote her biographer, 'she filled with holy images of Christ our Lord, of the Blessed Virgin and a great number of holy intercessors, in amongst brocades and tapestries. ${ }^{34}$

His confreres told the tribunal that it had been Brother Geremia himself, appointed by the Princess, who gave directions to the artist who painted the work on the subject it should depict: a vision of the Madonna which had appeared to him in a dream [Figs 6.6 and 6.7]. He, 'had it painted', confirmed several monks at the tribunal, 'by an artist, at the insistence of the elderly Princess

32 On the acceptance of the Franciscans into the Kingdom of Naples and the south of Italy in general, see Galasso G., L'altra Europa 110-115.

33 For rituals performed at the death of servants of God, and in particular for the scavenging of relics from the body of Brother Geremia da Valacchia, see Sodano G., Modelli e selezione del santo moderno. Periferia napoletana e centro romano (Naples: 2002) 181-193. BNN, ms. XI A 52, Della vita e morte dell'Ill.ma et Ecc.ma S.ra Donna Isabella Feltria Della Rovere, Principessa di Bisignano, fol. 53 r. 


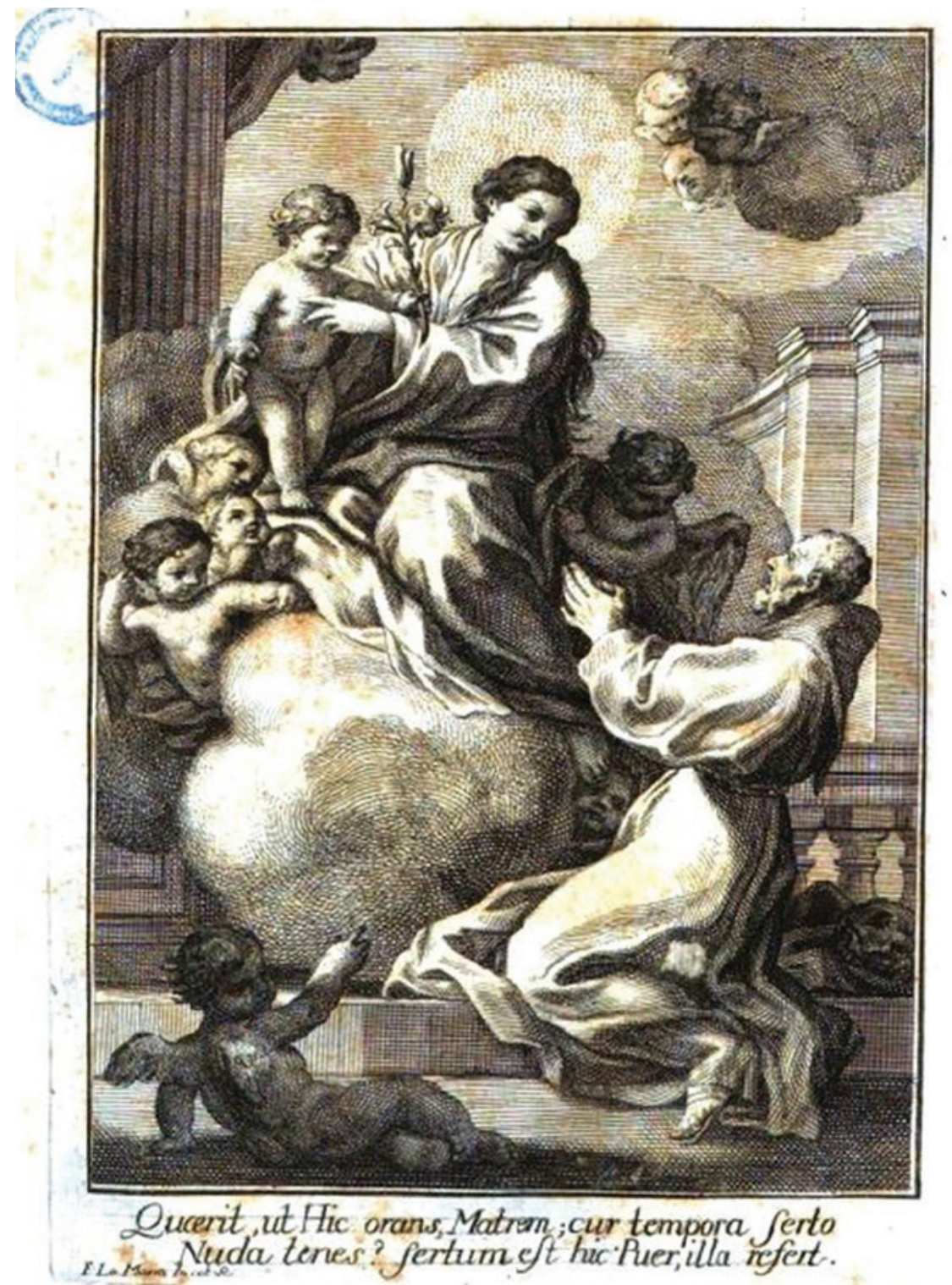

FIGURE 6.6 Friar Emanuele from Naples, Vita del venerabile servo di Dio Frate Geremia da Valacchia de' Minori Cappuccini della Provincia di Napoli (Naples 1761) 


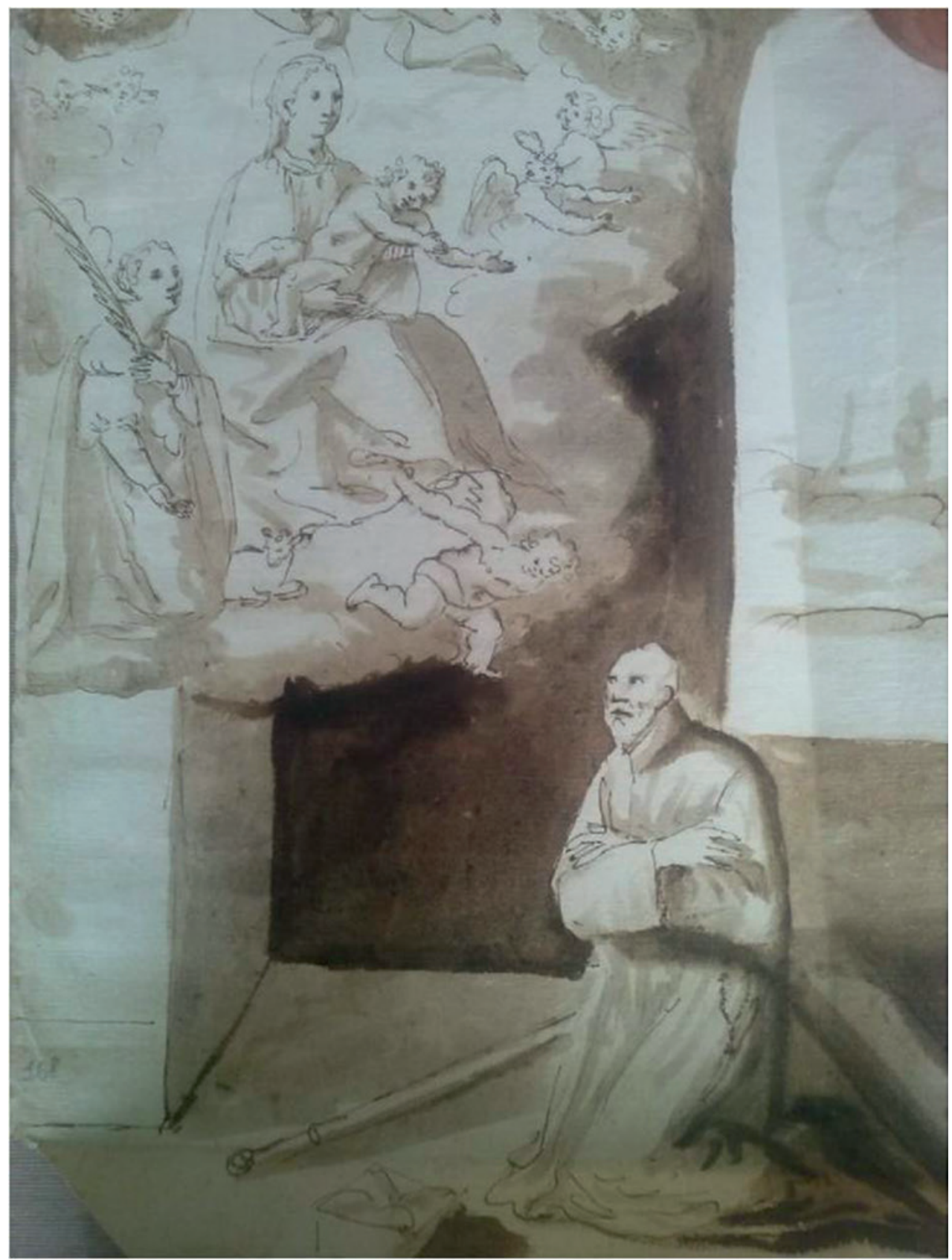

FIGURE 6.7 The vision of Madonna, BNN, ms. XI A 52, ca. n.n (C) BIBLIOTECA NAZIONALE DI NAPOLI 
of Bisignano, sister to the Duke of Urbino - the same image of the Most Holy Madonna in just the way he described, and as the painter was not sure how to go about it (there being in the lady's house many other paintings depicting the Blessed Virgin), Brother Geremia advised him to 'take a little from this one, and a little from that'.35

As in the vision, the painting shows Mary with a white dress interwoven with stars, bareheaded, her hair loose on her shoulders, and the Christ Child held in her right arm. This Marian iconography was unusual in Naples at that time because of the lack of a crown or veil on her head, in contrast with other images in both private collections and ecclesiastical ones. ${ }^{36}$ At any rate, the depiction immediately found much favour: witnesses at the beatification process of Brother Geremia said that it was reproduced in a great many copies dispersed around Naples and also outside the city, as far, indeed, as Slovenia and Moldavia, the native lands of Brother Geremia. It was known as 'Brother Geremia's Madonna': 'Thus so many of these images were painted in the manner described by Brother Geremia,' his confreres recounted, 'that they not only filled Naples, but spread throughout Italy and even beyond its confines'. ${ }^{37}$ The iconographic model in question was presumably a serene, intimate and emotional image of motherhood possibly similar to the style of the Madonnas by Federico Barocci, a painter who enjoyed great success at the court of the Della Rovere in Urbino as well as, following Isabella's introduction, the court of the viceroy of Naples and even Madrid. ${ }^{38}$

We know that a copy of the painting hung, at least till the late eighteenth century, in the Chiesa della Immacolata Concezione. The subject matter was also frequently replicated in wooden sculptures. Inside domestic spaces, in the Princess' rooms, the painting expressed, among its other possible meanings, maternity and childhood. For its unhappy owner, disappointed so many times as a wife and mother, it must have served a talismanic function, given that it

35 ASDn, Fondo Cause dei Santi, 26, Geremia da Valacchia, f. n.n.

36 See De Maio R., Pittura e Controriforma a Napoli (Rome-Bari: 1983) and more recently Labrot G., Peinture et société à Naples. XVI-XVII siècle: Commandes Collections Marchés, Préface de Aymard M. (Seyssel: 2010).

37 ASDn, Fondo Cause dei Santi, 26, Geremia da Valacchia, f. n.n.; Emmanuele da Napoli, Vita del Venerabile Servo di Dio frate Geremia da Valacchia 98.

38 Morselli R., "Nove quadri per il duca. Quello che resta delle opere di Federico Barocci nella collezione di Franceco Maria della Rovere nel 1631", in Continisio C. - Fantoni M. (eds.), Testi e contesti. Per Amedeo Quondam (Rome: 2015) 329-343. 
showed a mother with a son who was the sole heir of a great dynasty, who had similarly died young. With its moral and emotional content, the image of Mary as a mother taking care of her Child represented a sort of image-amulet of motherhood. ${ }^{39}$ Outside the domestic space of the Sanseverino di Bisignano Palace, the painting represented the visions of a venerable monk from foreign lands, and was a multivalent thaumaturgic object. Brother Geremia himself made use of it when he was gravely ill, when he had the painting brought from the Princess to the monastery. There, in the intimate space of his cell (following a recurrent theme in miracles obtained via the intercession of the Madonna), he invoked the Virgin directly, touching and kissing the sacred image, which resulted in a remarkable recovery, thus revealing the extraordinary thaumaturgic power of the image. ${ }^{40}$

From then on, the fame of the image took a meandering path between Naples and Moldavia, tracing the route of the trip which Brother Geremia had taken, from his parents' guidance in Moldavia to the material and spiritual apostolate movement which he carried out among the sick of Spanish Naples. Thanks to the actions of missionary Capuchins, copies of the same subject sculpted in wood would also reach overseas territories.

The painting of Brother Geremia's Madonna found in the Princess of Bisignano's palace was a devotional image that was reproduced in many and widespread examples, one of those numerous 'everyday objects', brimming with emotional and affective potential, which filled domestic and ecclesiastical spaces of the time and which today attract the attention of historians of material culture and of domestic religion. ${ }^{41}$

39 Miller S.R., "Parenting in the Palazzo: Images and Artifacts of Children in the Italian Renaissance Home", in Campbell E.J. - Miller S.R. - Carrol Consavari E. (eds.), The Early Modern Italian Domestic Interior, 1400-170o Objects, Spaces, Domesticities (Burlington: 2013) 67-88. On the reassessment of maternal tenderness towards their children, see D'Amelia M, "La presenza delle madri nell'Italia medievale e moderna”, in D'Amelia M. (ed.), Storia della maternità (Rome-Bari: 1997) $3{ }^{-52 . O n}$ the dissemination in Naples of cults linked to a new sensitivity towards childhood see Scaramella P., I santolilli. Culti dell'infanzia e santità infantile a Napoli alla fine del XVII secolo (Rome: 1997).

40 Casper A.R., "Display and Devotion: Exhibiting Icons and Their Copies in CounterReformation Italy", in De Boer W. - Göttler Ch. (eds.), Religion and the Senses in Early Modern Europe (Leiden - Boston: 2013) 43-62. On recurring elements in visions of the Virgin and Marian miracles see Sodano G., Il miracolo nel Mezzogiorno d'Italia 87-96.

41 See Hamling T. - Richardson C., Everyday objects. Medieval and Early Modern Material Culture and its Meanings (Farnham: 2010). 
This episode, and the devotional image at its centre (which are extensively documented in sources relating to both the protagonists), can be considered emblematic of those which can be grouped together under the heading of 'domestic religion'. Both the image and the episode highlight above all the very close relationship between religious belief, with its transcendental, moral and emotional content, and the tangible experience of believers. This relationship is exemplified by devotion to Mary, as a compassionate mother who endures adversity, and the long-awaited, disappointing experience of motherhood of the unfortunate princess. This materialised in devotion to a miraculous image, and in faith in the power of the intercession of the Madonna - as we have seen, both widely-diffused aspects of religious life among Catholic populations in Southern Italy, and more generally in many areas of the early modern Mediterranean. ${ }^{42}$

The Princess of Bisignano's domestic space and Brother Geremia's cell represent both physical spaces and metaphorical spaces. They were spaces for intimacy and for prayer, for spiritual pain and for physical sickness. They were also spaces for sociability: aristocratic sociability in the Princess' court, with her lively social network consisting of cultural connections and exchanges of religious relics, scientific instruments, and artistic artefacts with the Della Rovere family in Pesaro and Urbino, the Farnese in Rome, the Viceroys of Naples, the counts of Lemos and Miranda, and the Habsburgs in Madrid; religious sociability among the brothers of the monastery of the Santissima Concezione in Naples and a band of faithful followers. They were both, therefore, physical places for religious practice, but also above all they were permeable spaces which were open to interaction between the internal and the external, that is between the house or convent, and the multitude of worshippers in a multiethnic, kaleidoscopic city characterised by strong socio-cultural mobility, as the capital of the Kingdom of Naples was at the time.

42 On the sixteenth-century prevalence of Marian devotion and on the worship of images which reproduced less common Christological visions see Galasso G., L'altra Europa 9195; Christian W.A. jr., Local religion in sixteenth century Spain (Princeton, NJ: 1981) 71-91. On the predominance of Mary in religious iconography within domestic interiors see Labrot G., Collections of Paintings in Naples. 1600-1780 (Munich-London-New York-Paris: 1992) 585-680; Revenga Domínguez P., Pintura y sociedad en el Toledo Barroco (Junta Comunidades de Castilla-La Mancha: 2002) 357-366. 
The domestic space of the Princess of Bisignano was also a space for the religion of 'things'. It was a space overflowing with objects of impressive diversity: both in the Cassano Palace in Calabria and in the Chiaia Palace in Naples, the princess's rooms were stuffed with sacred images (of the Virgin, of the Passion of Christ and of a great number of saints), instruments for self discipline, agnus dei, rosaries, paternoster beads in wood, ebony, gemstones and various other materials, stashed in chests covered in silk or velvet, next to more precious jewels or on more expensive furniture. The apartments of her husband the Prince, on the other hand, were arranged along completely different lines. First and foremost, they contained not one single devotional object. In their place were leather and velvet furnishings, tapestries, carpets, cushions, weapons, musical instruments, silverware, portraits, and mythological or landscape paintings. ${ }^{43}$ It was the Princess who had personally attended to furnishing the private oratory within the palace in Naples. Here, nestled next to crucifixes, candelabras and other silver ornaments was her extraordinary collection of relics, gathered mainly thanks to connections with her mother's side of the Farnese family in Rome. ${ }^{44}$

The Princess of Bisignano's domestic space was also a fluid and plural space. It was a point of intersection for the religious requests of several prominent aristocratic Italian families (the Della Rovere from Urbino, the Farnese from Rome, and the Sanseverino from Bisignano), as well as several Spanish ones (the counts and countesses of Lemos and Miranda), and the spiritual needs of the religious and faithful who gravitated towards a small convent in the busy,

43 The inventory of Sanseverino goods in the Calabrian residence has been examined by Galasso G., "Aspetti e problemi della società feudale napoletana attraverso l'inventario dei beni dei Principi di Bisignano (1594)", in Studi in memoria di Federigo Melis (Naples: 1978) vol. IV, 255-277. The document in question is in ASN, Diversi della Sommaria, II Numerazione, 147. The Princess of Bisignano's will with the inventory of her personal possessions is in Notai XVI secolo, Notaio Francesco Antonio Stinca, 503/17, incc. 78, 82, 83. On the typology of the genre of devotional objects see Palumbo G., "Fede napoletana. Gli oggetti della devozione a Napoli: uno sguardo di genere", in Galasso G. - Valerio A. (eds.), Donne e religione a Napoli. Secoli XVI-XVIII (Milan: 2001) 285-310. More generally on female spaces in early modern Naples see Novi Chavarria E., "The Space of Women", in Astarita T. (ed.), A Companion to Early Modern Naples (Leiden - Boston: 2013) 177-196.

44 Sodano G., "Promozione dei culti e processi di canonizzazione nel Regno di Napoli in età moderna", in Pellegrino B. - Zarri G. - Michetti R. (eds.), Ordini religiosi, santi e culti tra Europa, mediterraneo e Nuovo Mondo (secoli $X V-X V I I$ ), Atti del V Convegno Internazionale AISSCA (Lecce, 3-6 maggio 2003) (Galatina: 2009) vol. I, 277-296: 287. 
working-class area of Vergini, outside Naples' city walls. The impact of this contact rippled out across the Mediterranean, reaching as far as Slovenia and distant Moldavia, the native land of our humble friar. Focused in that space and around the devotional object of Brother Geremia's Madonna was what amounted to the international (or, indeed, transnational) circulation of a global network of local groups and families. ${ }^{45}$

Weaving together these multiple connections, we see that domestic religion and domestic space are central in understanding the sensorial experience of visions and of contact with religious objects and the material culture of paintings, of little talismans, of the repeated gestures of the kiss, of the genuflection and of making the sign of the cross. It was thus that apparently distant devotional spaces were linked and communicated with each other via the content of visions, the circulation of relics and the narration of miracles spread by the religious zeal of friar Geremia's brothers and his devotees. ${ }^{46}$

Isabella Della Rovere has been depicted as a model of the spirit of the Counter Reformation. The domestic religion of Princess Isabella is emblematic of the ways in which forms of worship and devotion could cross social boundaries, connecting aristocratic environments in Naples, Rome and Urbino, high-ranking members of religious orders, and the humble followers of Brother Geremia. This domestic devotion oversteps national and local borders. It coexists in the same spaces where very different experiences and presences were felt. It inverts conventional models of centre and periphery. It is connected with other spaces and other historical actors and continuously criss-crossed by new agents and new devotions, in a network in constant motion. It represents the triumph of the material culture of religious objects (devotional images, rosaries, paternostri) and of sensory and emotional experiences.

45 An example of this sort of methodology can be found in Jonson Ch. J. - Sabean D.W. Teuscher S. -Trivellato F. (eds.), Transregional and Transnational Families in Europe and Beyond. Experiences Since the Middle Age (New Haven: 2011).

46 Emmanuele da Napoli, Vita del Venerabile Servo di Dio frate Geremia da Valacchia 155-156. On the circulation of the contents of visions via sermons see Novi Chavarria E., Sacro, pubblico e privato. Donne nei secoli XV-XVIII (Naples: 2009) 27-30. 


\author{
Abbreviations \\ AHN Archivo Historico Nacional, Madrid \\ ASDN Archivio Storico Diocesano di Napoli; Napoli \\ ASP Archivio Storico di Pesaro \\ BL British Library, London \\ BNN Biblioteca Nazionale di Napoli, Napoli
}

\title{
Archival Sources
}

ASDn, Fondo Cause dei Santi, 26, Geremia da Valacchia.

BNN, ms. I B 36, Masculo G.B. (S.J.), Isabellae Feltriae Roboreaque principis Bisiniani ducis Urbinatuium sororis Parentalia, a Patribus Societatis Jesu in templo domus professae B.M. soluta, Napoli 1619.

BNN, ms. XI A 52, Della vita e morte dell'Ill.ma et Ecc.ma S.ra Donna Isabella Feltria della Rovere, Principessa di Bisignano.

\section{Literature}

Astarita T. (ed.), A Companion to Early Modern Naples (Leiden - Boston: 2013).

De Boer W. - Göttler Ch. (eds.), Religion and the Senses in Early Modern Europe (Leiden - Boston: 2013).

Emmanuele da Napoli, Vita del Venerabile Servo di Dio frate Geremia da Valacchia de' Minori Cappuccini della Provincia di Napoli (Naples, Vincenzo Pauria: 1761).

Galasso G., L'altra Europa. Per un'antropologia storica del Mezzogiorno d'Italia (Naples: $\left.2009^{3}\right)$.

Galasso G. - Valerio A. (eds), Donne e religione a Napoli. SecoliXVI-XVIII (Milan: 2001). Jonson Ch. J. - Sabean D.W. - Teuscher S. - Trivellato F. (eds), Transregional and Transnational Families in Europe and Beyond. Experiences Since the Middle Age (New Haven: 2011).

Novi Chavarria E., "Dame di corte, circolazione dei saperi e degli oggetti nel Rinascimento meridionale”, in Santoro M. (ed.), La Donna nel Rinascimento meridionale (Pisa-Rome: 2010), 215-225.

Novi Chavarria E., "The Space of Women", in Astarita T. (ed.), A Companion to Early Modern Naples (Leiden - Boston: 2013) 177-196.

Novi Chavarria E., Sacro, pubblico e privato. Donne nei secoli XV-XVIII (Naples: 2009). 
Pérez de Tuleda Gabaldón A., "Las relaciones artísticas de la familia della Rovere con la corte española durante el reinado de Felipe in en la correspondencia del Archivo de Estado de Florencia", in Martínez Millán J., Rivero Rodríguez M. (eds.), Centros de poder italianos en la monarquía hispánica (siglos XV-XVIII) (Madrid: 2010) vol. III: 1543-1714.

Sodano G., Il miracolo nel Mezzogiorno d'Italia dell'età moderna tra Santi, Madonne, guaritrici e medici (Naples: 2010).

Verstegen I.F. (ed.), Patronage and Dynasty: the Rise of the della Rovere in Renaissance Italy (Kirksville, MI: 2007). 